7. Водолажская М.Г., Чадова И.Н. Динамика ЭЭГ лиц женского пола в течение овариальноменструального цикла (ОМЦ) // Вестник Северо-Кавказского федерального университета. 2013. № 5. С. $111-114$.

8. Водолажская М. Г., Водолажский Г. И., Чадова И.Н. Подробное исследование онтогенетических изменений параметров ЭЭГ мужчин и женщин в течение репродуктивного периода // Российский физиологический журнал им. И. М. Сеченова. 2015. № 5. С. 614-626.

9. Вольф Н.В., Глухих А.А. Фоновая электрическая активность мозга при «успешном» ментальном старении // Физиология человека. 2011. № 5. С. 51-60.

10. Жаворонкова Л. Правши и левши // наука в России. - 2007. -№ 3. - С. 31-37;

11. Кичигина В.Ф. Механизмы регуляции и функциональное значение тета-ритма: роль серотонинергической и норадренергической систем // Журнал высшей нервной деятельности. 2004. № 1. С. 101-119.

12. Куксова Н.С. К вопросу об источниках генерации медленной активности на ЭЭГ // ХХ съезд Физиологического общества им. И. П. Павлова. Тезисы докладов. Москва: Изд-во «Русский врач», 2007. С. 294.

13. Свидерская Н.Е. Осозноваемая и неосозноваемая информация в когнитивной деятельности // Журнал высшей нервной деятельности. 1993. Т. 43. В.2. С. 271-277.

14. Татарчук Т.Ф., Бодрягова О.И. Дисфункциональные маточные кровотечения у женщин позднего репродуктивного возраста // Medix anti-aging. 2010. № 2. С. 78-88.

15. Федотова Ю.О., Сапронов Н.С. Эффекты эстрогенов в центральной нервной системе // Успехи физиологических наук. 2007. № 2. С. 46-62.

16. Чадова И.Н. Динамика электроэнцефалографии женщин в течение репродуктивного периода онтогенеза // Научное обозрение. 2014. № 1. С. 145-150.

17. Шеповальников А. Н., Цицерошин М. Н. Анализ пространственно-временной организации ЭЭГ путь к познанию нейрофизиологических механизмов интегративной деятельности мозга // Журнал высшей нервной деятельности им. И.П. Павлова. - 2007. - Т. 57, № 6. - С. 663-672;

18. Vodolazhskaya M., Vodolazhsky G., Naimanova M. Influence of Geophysical Factors on the Parameters of the Human Electroencephalogram / [et al.] // Biophysics. 2010. № 3. P.477-483.

19. Solis-Ortiz S., Guevara M., Corsi-Gabrera M. Performance in a test demanding prefrontal functions is favored by early luteal phase progesterone: an electroencephalographic study // Psychoneuroendocrinology. 2004. V. 29, № 8. P. 1047-1057;

\title{
Popov O.S., Novoselov A.S. \\ The macrostructure peculiarities of wood and Pinus Sylvestris undergrowth on boggy soil of the Vologda region
}

\author{
Vologda State University
}

(Russia, Vologda)

doi: 10.18411/scienceconf-05-2019-32

idsp: scienceconf-05-2019-32

\section{Abstract}

The main indicators of the pine macrostructure are reviewed and the peculiarities of its growth on the marshy and drained forest areas are identified. The wood samples taken in the crosscut end, are set the percentage of late wood in annual rings, the average number of layers in one centimeter and the width of the average annual ring is identified. The influence of the dehumidification works on the wood macrostructure is determined. Categories of the life state of coniferous undergrowth are established.

Key words: Scots Pine (Pinus sylvestris L.), the wood macrostructure, radial wood growth, pine undergrowth, hydrotechnical amelioration

Introduction. Forestry is one of the important branches in yield forest management and industry of the Vologda region. For successful and sustainable use of forest resources, it is necessary to consciously approach the issue of expanding forest areas. An event such as hydrotechnical amelioration, has a positive effect not only on the quality of wood, but also improves other parameters of forest stands [1]. 
Purpose of the study is to establish the peculiarities of growth of marshy pine forests and forest stands after hydrotechnical amelioration in Sokolsky and Ustyuzhensky state forest districts of the Vologda region.

To achieve the purpose, the following tasks were solved:

1) Pine forest stands growing in various forest growth conditions (naturally bogged and drained on mega- and mesotrophic peat deposits) are involved in the experiment;

2) Measurement works were carried out and silvicultural-taxation characteristics of the studied forest stands were determined;

3) The current average radial wood growth for the last five years is identified;

4) The ratio of the width of the late and early pine wood in various station conditions is studied;

5) Categories of life state of coniferous undergrowth are established;

6) Gradation of undergrowth by categories of size is identified.

Study objects description and method of works. The studies were undertaken in 2018 (summer period) on the territory of the Sokolsky (near the Sukhona river) and Ustyuzhensky (near the Shaloch river) state forest districts mainly in the anthropogenic pine forests of the southern subzone of coniferous boreal forests with different types of peat deposits (Fig. 1 ): naturally swamped coniferous-leafed forest stands (sample plot (SP) № 1 and 2 (Pinetum herboso-sphagnosa (SP № 1); control)) and drained on SP № $3-6$.

\section{Forest stands in Ustyuzhensky state forestry}

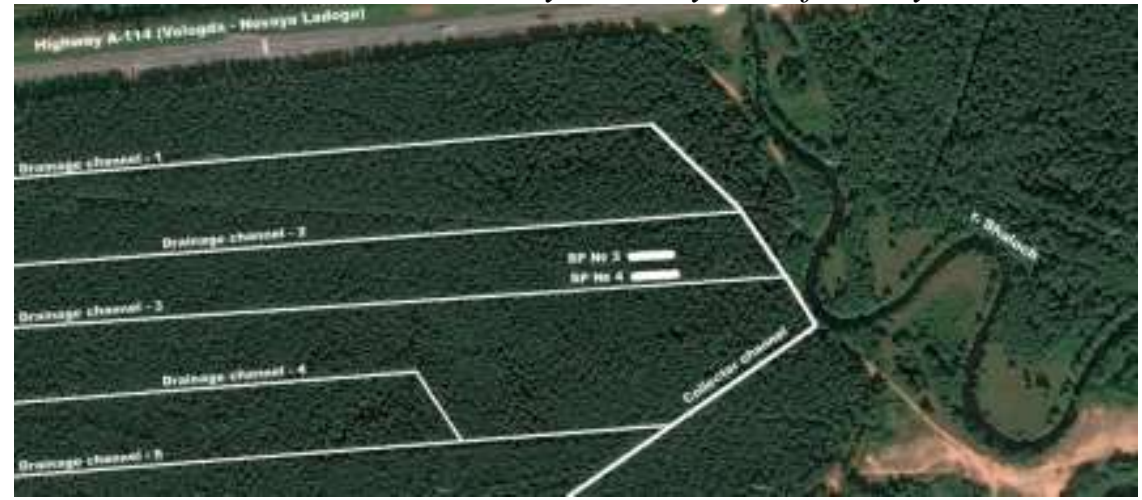

Forest stands in Sokolsky state forestry

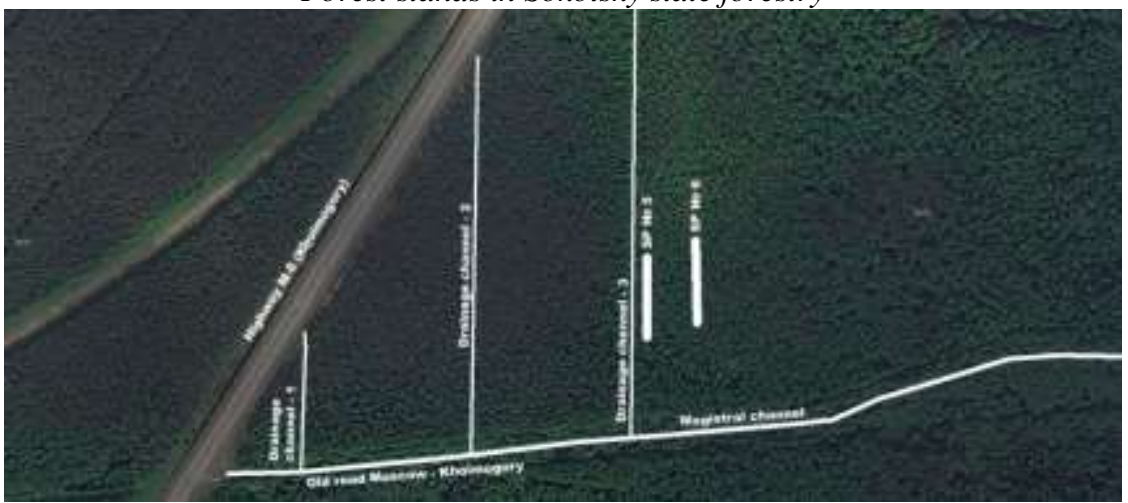

Fig. 1 - The layout of the study objects

With the help of a measuring tape, sample plots along the drainage channels were allocated. Tree heights were measured with an alidade and altimeter, taxation diameters at a height of $1.1 \mathrm{yd}(1.3 \mathrm{~m})$ were measured with callipers. The undergrowth was estimated by the gradation of the life state by I. S. Melekhov [2]. Reliable, reliable with technical defects, of dubious viability, non-viable and deadwood. Height measurements of young trees were carried out, which were divided into three categories of size: small (height up to $0.5 \mathrm{yd}(0.5 \mathrm{~m})$ ); medium (height $0.51-1.6 \mathrm{yd}(0.51-1.5 \mathrm{~m})$ ); and large (height above $1.61 \mathrm{yd}(1.51 \mathrm{~m})$ ). The remeasurement of undergrowth to the category "large" was carried out using coefficients $(0.5$ for 
small, 0.8 for medium and 1.0 for large). The cores for the study were selected by an age drill at a height of $0.7 \mathrm{yd}(0.6 \mathrm{~m})$ from the root collar, which were subsequently trimmed with a blade, tinted and marked for more accurate calculation of annual rings (Fig. 2). Images of processed cores were taken using a high-resolution scanner (a scale with increment of 0.002 inch $(0.05$ $\mathrm{mm}$ ) was developed). To obtain the accuracy of the experiment and the probability of $10 \%, 10$ accounting pine trees were selected for each sample plot [3].

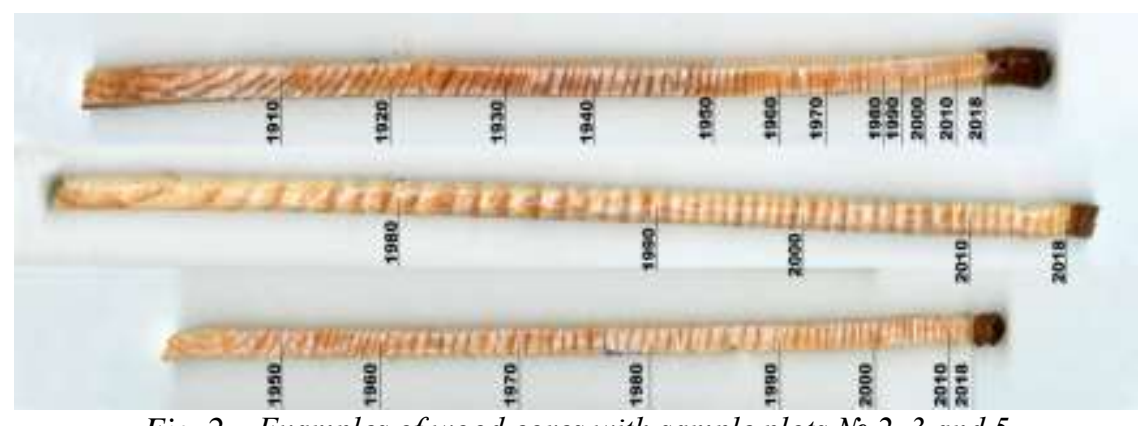

Fig. 2 - Examples of wood cores with sample plots № 2, 3 and 5

Results and discussion. An analysis of the taxation characteristics of forest stands growing in various conditions (Table 1) showed that the greatest average heights (34.4 yd (31.5 $\mathrm{m})$ ) and diameters $(10.6$ inches $(27.6 \mathrm{~cm}))$ are recorded in a dried bilberry pine. The maximum density of pine forest stands was recorded in the Pinetum herboso-sphagnosa, the largest growing stock was established in the bilberry pine forest.

Table 1.

Silvicultural-taxation characteristics of the studied forest stands

\begin{tabular}{|c|c|c|c|c|c|c|c|c|c|c|c|}
\hline \multirow[b]{3}{*}{ 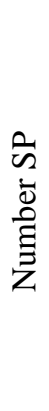 } & \multirow[b]{3}{*}{ 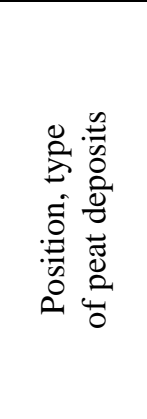 } & \multirow[b]{3}{*}{ 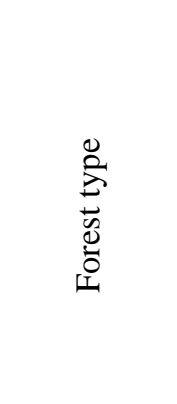 } & \multirow{3}{*}{ 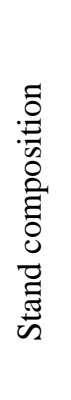 } & \multicolumn{8}{|c|}{ Averages } \\
\hline & & & & \multirow[b]{2}{*}{ 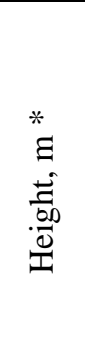 } & \multirow[b]{2}{*}{ 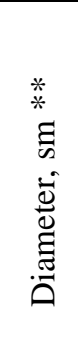 } & \multirow[b]{2}{*}{ 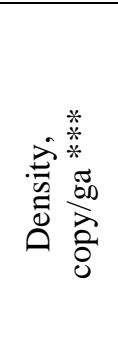 } & \multicolumn{2}{|c|}{ Fullness } & \multirow[b]{2}{*}{$\begin{array}{l}\mathscr{\mathscr { D }} \\
\mathscr{\mathscr { n }}\end{array}$} & \multicolumn{2}{|c|}{$\begin{array}{c}\text { Stock, m3/ga } \\
* * * * *\end{array}$} \\
\hline & & & & & & & 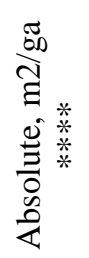 & $\frac{\sum_{\tilde{J}}^{2}}{\mathscr{a}}$ & & : & $\stackrel{\overrightarrow{0}}{\vec{D}}$ \\
\hline \multicolumn{12}{|c|}{ Naturally swampy conditions (Sokolsky forestry) } \\
\hline \multirow{3}{*}{1} & \multirow{3}{*}{$\begin{array}{c}-, \\
\text { Megatrop } \\
\text { hic }\end{array}$} & \multirow{3}{*}{ 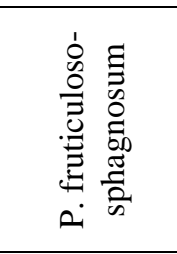 } & \multirow{3}{*}{ 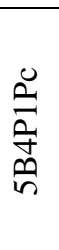 } & $\begin{array}{l}19,9 \\
21,8\end{array}$ & $\begin{array}{l}61,2 \\
24,1\end{array}$ & $\begin{array}{c}1135,8 \\
460,0\end{array}$ & $\begin{array}{l}44,2 \\
21,4\end{array}$ & 0,6 & $\begin{array}{c}\text { Pinus } \\
\text { (P) }\end{array}$ & $\begin{array}{l}421,3 \\
223,2\end{array}$ & $\begin{array}{l}32,3 \\
17,1\end{array}$ \\
\hline & & & & $\begin{array}{l}19,0 \\
20,8\end{array}$ & $\begin{array}{l}45,7 \\
18,0\end{array}$ & $\begin{array}{c}1679,0 \\
680,0\end{array}$ & $\begin{array}{l}39,0 \\
18,9\end{array}$ & 0,7 & $\begin{array}{l}\text { Betula } \\
\text { (B) }\end{array}$ & $\begin{array}{l}332,6 \\
176,2\end{array}$ & $\begin{array}{c}16,2 \\
8,6\end{array}$ \\
\hline & & & & $\begin{array}{l}13,7 \\
15,0\end{array}$ & $\begin{array}{l}30,0 \\
11,8\end{array}$ & $\begin{array}{l}296,3 \\
120,0\end{array}$ & $\begin{array}{l}2,7 \\
1,3\end{array}$ & 0,1 & $\begin{array}{c}\text { Picea } \\
(\mathrm{Pc})\end{array}$ & $\begin{array}{l}19,2 \\
10,2\end{array}$ & $\begin{array}{l}5,3 \\
2,8\end{array}$ \\
\hline \multirow{2}{*}{2} & \multirow{2}{*}{$\begin{array}{c}\text { C, } \\
\text { Mesotrop } \\
\text { hic }\end{array}$} & \multirow{2}{*}{$\begin{array}{l}\text { P. herboso- } \\
\text { sphagnosa }\end{array}$} & \multirow{2}{*}{$\frac{n}{a}$} & $\begin{array}{l}20,1 \\
22,0\end{array}$ & $\begin{array}{l}50,5 \\
19,9\end{array}$ & $\begin{array}{l}2518,5 \\
1020,0\end{array}$ & $\begin{array}{l}68,1 \\
33,0\end{array}$ & 0,9 & $\mathrm{P}$ & $\begin{array}{l}648,8 \\
343,7\end{array}$ & $\begin{array}{l}62,7 \\
33,3\end{array}$ \\
\hline & & & & $\begin{array}{l}15,1 \\
16,5\end{array}$ & $\begin{array}{l}34,8 \\
13,7\end{array}$ & $\begin{array}{l}395,1 \\
160,0\end{array}$ & $\begin{array}{l}5,2 \\
2,5\end{array}$ & 0,1 & B & $\begin{array}{l}34,5 \\
18,3\end{array}$ & $\begin{array}{l}3,0 \\
1,6\end{array}$ \\
\hline \multicolumn{12}{|c|}{ Intensively drained conditions (98 yds ( $90 \mathrm{~m}$ ) ditch spacing) } \\
\hline \multirow{3}{*}{3} & $\frac{.}{\frac{\pi}{2}}$ & \multirow{5}{*}{ 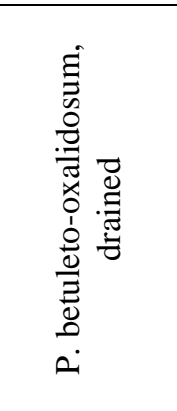 } & \multirow{3}{*}{ 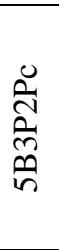 } & $\begin{array}{l}19,0 \\
20,8\end{array}$ & $\begin{array}{l}45,5 \\
17,9\end{array}$ & $\begin{array}{c}2123,5 \\
860,0\end{array}$ & $\begin{array}{l}50,2 \\
24,3\end{array}$ & 0,9 & B & $\begin{array}{l}427,6 \\
226,5\end{array}$ & $\begin{array}{l}3,4 \\
1,8\end{array}$ \\
\hline & $\begin{array}{l}5 \\
0 \\
0 \\
0\end{array}$ & & & $\begin{array}{l}22,9 \\
25,0\end{array}$ & $\begin{array}{l}49,5 \\
19,5\end{array}$ & $\begin{array}{l}987,6 \\
400,0\end{array}$ & $\begin{array}{l}26,4 \\
12,8\end{array}$ & 0,3 & $\mathrm{P}$ & $\begin{array}{l}281,7 \\
149,2\end{array}$ & $\begin{array}{c}10,9 \\
5,8\end{array}$ \\
\hline & $\sum$ & & & $\begin{array}{l}12,8 \\
14,0\end{array}$ & $\begin{array}{l}34,3 \\
13,5\end{array}$ & $\begin{array}{l}790,1 \\
320,0\end{array}$ & $\begin{array}{l}8,5 \\
4,1\end{array}$ & 0,2 & Pc & $\begin{array}{l}56,3 \\
29,8\end{array}$ & 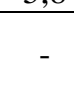 \\
\hline \multirow{2}{*}{4} & \multirow{2}{*}{$\begin{array}{c}\text { IC, } \\
\text { Mesotrop } \\
\text { hic }\end{array}$} & & \multirow{2}{*}{ ڤે } & $\begin{array}{l}18,3 \\
20,0 \\
\end{array}$ & $\begin{array}{l}52,8 \\
20,8 \\
\end{array}$ & $\begin{array}{c}1728,4 \\
700,0 \\
\end{array}$ & $\begin{array}{l}51,2 \\
24,8 \\
\end{array}$ & 0,7 & $\mathrm{P}$ & $\begin{array}{l}450,4 \\
238,6\end{array}$ & $\begin{array}{l}81,7 \\
43,3 \\
\end{array}$ \\
\hline & & & & $\begin{array}{l}13,3 \\
14,6\end{array}$ & $\begin{array}{l}36,3 \\
14,3 \\
\end{array}$ & $\begin{array}{l}790,1 \\
320,0\end{array}$ & $\begin{array}{c}11,6 \\
5,6\end{array}$ & 0,2 & Pc & $\begin{array}{l}81,2 \\
43,0 \\
\end{array}$ & - \\
\hline
\end{tabular}




\begin{tabular}{|c|c|c|c|c|c|c|c|c|c|c|c|}
\hline \multicolumn{12}{|c|}{ Extensively drained conditions (131 yds (120 m) ditch spacing) } \\
\hline \multirow{2}{*}{5} & \multirow{2}{*}{$\begin{array}{c}\text { CS } \\
\text { Mesotrop } \\
\text { hic }\end{array}$} & \multirow{5}{*}{ 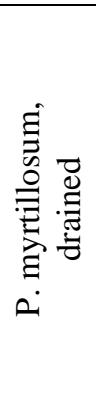 } & \multirow{2}{*}{$\underset{\infty}{\stackrel{\infty}{\infty}} \stackrel{0}{+}+$} & $\begin{array}{l}22,4 \\
24,5\end{array}$ & $\begin{array}{l}52,8 \\
20,8\end{array}$ & $\begin{array}{c}1530,9 \\
620,0\end{array}$ & $\begin{array}{l}45,6 \\
22,1\end{array}$ & 0,5 & $\mathrm{P}$ & $\begin{array}{l}468,4 \\
248,1\end{array}$ & $\begin{array}{l}24,7 \\
13,1\end{array}$ \\
\hline & & & & $\begin{array}{l}19,4 \\
21,2 \\
\end{array}$ & $\begin{array}{l}47,0 \\
18,5 \\
\end{array}$ & $\begin{array}{l}592,6 \\
240,0 \\
\end{array}$ & $\begin{array}{c}16,1 \\
7,8 \\
\end{array}$ & 0,3 & B & $\begin{array}{c}137,4 \\
72,8 \\
\end{array}$ & - \\
\hline \multirow{3}{*}{6} & \multirow{3}{*}{ 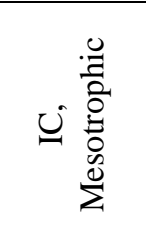 } & & \multirow{3}{*}{$\begin{array}{l}0 \\
\vdots \\
\dot{z} \\
n \\
n\end{array}$} & $\begin{array}{l}28,8 \\
31,5 \\
\end{array}$ & $\begin{array}{l}70,1 \\
27,6\end{array}$ & $\begin{array}{l}296,3 \\
120,0\end{array}$ & $\begin{array}{l}51,0 \\
24,7\end{array}$ & 0,5 & $\mathrm{P}$ & $\begin{array}{l}656,2 \\
347,6\end{array}$ & $\begin{array}{l}60,6 \\
32,1 \\
\end{array}$ \\
\hline & & & & $\begin{array}{l}23,4 \\
25,6 \\
\end{array}$ & $\begin{array}{l}47,7 \\
18,8 \\
\end{array}$ & $\begin{array}{c}1283,9 \\
520,0\end{array}$ & $\begin{array}{l}32,2 \\
15,6\end{array}$ & 0,5 & B & $\begin{array}{l}330,0 \\
174,8\end{array}$ & - \\
\hline & & & & $\begin{array}{l}10,9 \\
11,9\end{array}$ & $\begin{array}{l}36,6 \\
14,4\end{array}$ & $\begin{array}{l}987,6 \\
400,0\end{array}$ & $\begin{array}{l}4,1 \\
2,0\end{array}$ & 0,1 & $\mathrm{Pc}$ & $\begin{array}{l}24,3 \\
12,9\end{array}$ & - \\
\hline
\end{tabular}

Footnote: in numerator - imperial units, in denominator-metric units, ${ }^{*}-y a r d, * *-i n c h$, $* * *-a c r e, * * * *-y a r d^{2} / a c r e, * * * * *-y a r d^{3} / a c r e$, position of pine forests in the drained space-CS-canalside (IC) - interchannel, $C$ - control.

Studying the percentage of late wood in annual rings, it should be noted that its largest percentage is set in trees at SP number 3 (Fig. 2). The percentage of late wood is $6.2 \%$ higher in drained stands, relatively waterlogged.

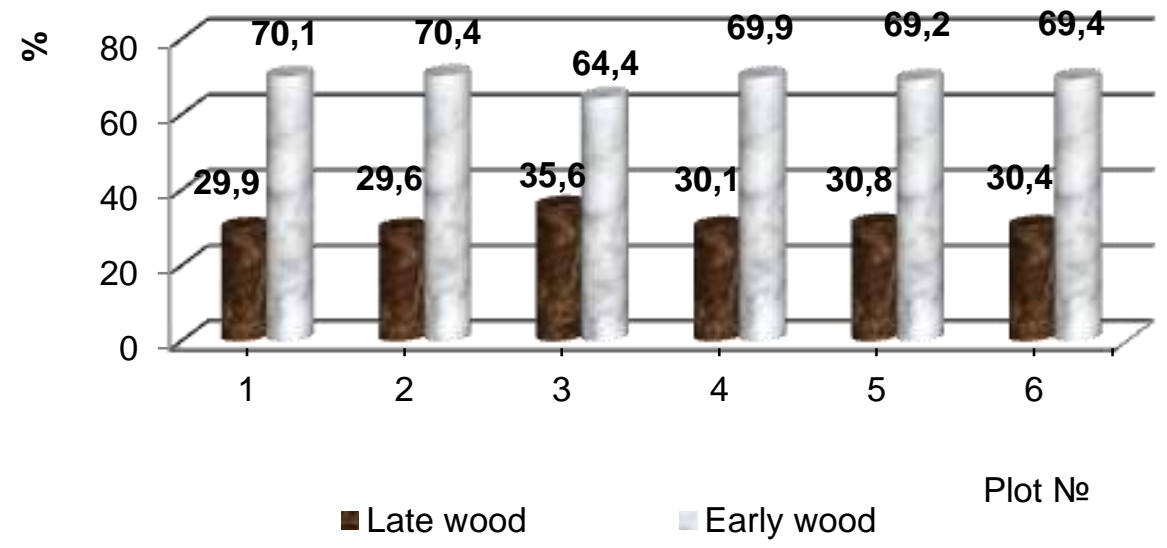

Fig. 2 - Average late and early wood content

The greatest number of annual layers in one centimeter of growth (Fig. 3) of wood in the sample plots was found in the marshy pine-tree of fruticuloso-sphagnosum with megatrophic peat soils and on the interchannel area in drained bilberry pine forest. The smallest indicators were found in the marshy Pinetum herboso-sphagnosa and in the center of the interchannel position of the dried sorrel pinery.

Comparing the average width of the annual ring of pine (Table 2) on the transitional type of peat deposit, it was found that it is higher in drained forest stands than in the marshy control (by $63 \%$, respectively). In drained forest stands, this figure varies between 0.001 inch $(0.25$ $\mathrm{mm})$.

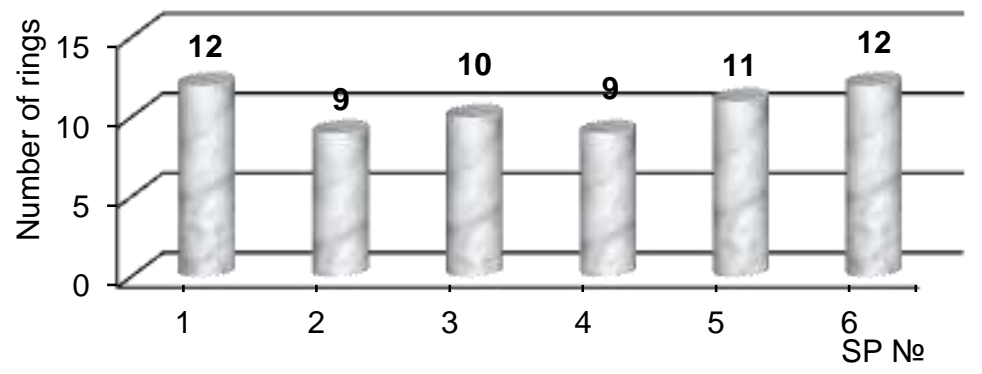

Fig. 3 - The average number of annual rings per centimeter

According to the results of the analysis of the number of annual rings in one centimeter, it was established that in drained forest stands, this figure is $33 \%$ higher than in marshy pine 
forests. Consequently, the intensity of cambium activity in the forest stands after hydrotechnical amelioration is higher, but the quality of wood in the control objects will be better due to the greater hardness.

Table 2.

Pine wood macrostructure indicators at the study objects

\begin{tabular}{|c|c|c|c|c|c|c|}
\hline \multirow[b]{2}{*}{$\begin{array}{l}\text { Macrostructu } \\
\text { re indicators }\end{array}$} & \multicolumn{6}{|c|}{ Number SP, mean age (years), position of pine forests in the drained space } \\
\hline & $\begin{array}{c}\text { 1, P. fr.- } \\
\text { sphag., } 108, \\
\text { C }\end{array}$ & $\begin{array}{c}\text { 2, P. herb.- } \\
\text { sphag., } 116, \\
\text { C }\end{array}$ & $\begin{array}{l}\text { 3, P. bet. - } \\
\text { oxal., dr., } 46 \text {, } \\
\text { CS }\end{array}$ & $\begin{array}{c}\text { 4, P. bet. - } \\
\text { oxal., dr., } 43 \text {, } \\
\text { IC }\end{array}$ & $\begin{array}{l}\text { 5, P. myrt., } \\
\text { dr., 64, CS }\end{array}$ & $\begin{array}{l}\text { 6, P. myrt., } \\
\text { dr., 66, IC }\end{array}$ \\
\hline $\begin{array}{c}\text { LW } \\
\text { percentage }\end{array}$ & $29,89 \pm 1,67$ & $29,60 \pm 1,45$ & $35,56 \pm 1,64$ & $30,10 \pm 1,11$ & $30,80 \pm 1,02$ & $30,40 \pm 2,08$ \\
\hline $\begin{array}{l}\mathrm{ARW}, \mathrm{mm} \\
(\mathrm{M} \pm \mathrm{mM}),{ }^{*}\end{array}$ & $\begin{array}{c}0,040 \pm \\
0,003 \\
1,01 \pm 0,07\end{array}$ & $\begin{array}{c}0,009 \pm \\
0,001 \\
0,23 \pm 0,02\end{array}$ & $\begin{array}{c}0,031 \pm \\
0,003 \\
0,79 \pm 0,07\end{array}$ & $\begin{array}{c}0,025 \pm \\
0,002 \\
0,64 \pm 0,04\end{array}$ & $\begin{array}{c}0,021 \pm \\
0,002 \\
0,54 \pm 0,04\end{array}$ & $\begin{array}{c}0,021 \pm \\
0,002 \\
0,55 \pm 0,04\end{array}$ \\
\hline $\begin{array}{l}\text { ARW in the } \\
\text { last } 5 \text { years, } \\
\text { mm } \\
(\mathrm{M} \pm \mathrm{mM}), *\end{array}$ & $\begin{array}{c}0,024 \pm \\
0,002 \\
0,62 \pm 0,04\end{array}$ & $\begin{array}{c}0,022 \pm \\
0,002 \\
0,56 \pm 0,04\end{array}$ & $\begin{array}{c}0,039 \pm \\
0,003 \\
0,99 \pm 0,09\end{array}$ & $\begin{array}{c}0,049 \pm \\
0,004 \\
1,24 \pm 0,11\end{array}$ & $\begin{array}{c}0,026 \pm \\
0,002 \\
0,67 \pm 0,04\end{array}$ & $\begin{array}{c}0,024 \pm \\
0,001 \\
0,61 \pm 0,03\end{array}$ \\
\hline $\begin{array}{l}\text { Number of } \\
\text { annual layers } \\
\text { in } 1 \mathrm{sm} \\
(\mathrm{M} \pm \mathrm{mM}), *\end{array}$ & $\begin{array}{l}3,59 \pm 0,61 \\
9,11 \pm 1,54\end{array}$ & $\begin{array}{c}5,43 \pm 1,15 \\
13,79 \pm 2,91\end{array}$ & $\begin{array}{l}1,95 \pm 0,42 \\
4,95 \pm 1,07\end{array}$ & $\begin{array}{l}1,95 \pm 0,27 \\
4,96 \pm 0,69\end{array}$ & $\begin{array}{l}2,29 \pm 0,35 \\
5,81 \pm 0,89\end{array}$ & $\begin{array}{l}2,30 \pm 0,46 \\
5,85 \pm 1,16\end{array}$ \\
\hline $\begin{array}{c}\text { «Signal- } \\
\text { noise» SNR }\end{array}$ & 13,30 & 7,29 & 20,73 & 17,01 & 12,02 & 29,68 \\
\hline $\begin{array}{l}\text { Autocorrelati } \\
\text { on (r) }\end{array}$ & 0,60 & 0,42 & 0,70 & 0,63 & 0,55 & 0,75 \\
\hline $\begin{array}{c}\text { Average } \\
\text { current } \\
\text { growth (in } \\
\text { mm) for } 5 \\
\text { years, * }\end{array}$ & $\begin{array}{l}0,12 \\
3,11\end{array}$ & $\begin{array}{l}0,11 \\
2,82\end{array}$ & $\begin{array}{l}0,19 \\
4,94\end{array}$ & $\begin{array}{l}0,22 \\
5,56\end{array}$ & $\begin{array}{l}0,13 \\
3,35\end{array}$ & $\begin{array}{l}0,12 \\
3,04\end{array}$ \\
\hline
\end{tabular}

Footnote: LW-late wood, $(A R W))$ - annual ring width, *- inch, SNR calculated by the method [4], bold highs in averages.

In the course of determining the categories of the life state of pine undergrowth in wetlands, the prevalence of reliable young undergrowth was identified $-41 \%$. Dubious young trees make up only $12 \%$ on average of their total number. The number of young trees transformed into larger is higher in the forest stand on the megatrophic type of peat deposit (849 specimens / acre (344 specimens / ha) five times, relatively marshy pine forest with mesotrophic feeding of the soil. In marshy forest stands, prevalence of coniferous undergrowth was established with category "reliable with defects".

In intensively drained forest stands, fir undergrowth of medium size $(68 \%)$ prevails, and the category "large" makes up only $30 \%$. In extensively drained forest stands, the predominance of large undergrowth was recorded $-56 \%$. Small undergrowth in such conditions of water regime is absent. The number of young fir trees in intensively drained conditions is four times higher than in extensively drained ones.

On average, in drained conditions, fir young trees of the category of deadwood (32\%) prevails, the smallest percentage of representation is fixed among the reliable defectless undergrowth $(18 \%)$. Reliable defectless undergrowth is more fixed near the canals relative to the center of the drained space by $7 \%$. The largest amount of coniferous undergrowth was found in the center of the interchannel space of the intensively drained pine forest stand - 258 copies / acre (646 copies / ha), respectively.

As a result of calculating the average radial growth of late wood by decades, it was found that the smallest values in diameter were recorded in marshy conditions $(0.090$ inch $(2.3$ $\mathrm{mm})$ vs. 0.236 inch $(6.1 \mathrm{~mm})$ on average in drained conditions). The highest age of the studied woods was recorded in the marshy conditions (Table 2), relative to other objects of the study. When comparing natural-marshy forest stands, a larger radial growth was detected on the object 
with a megatrophic type of peat deposit relatively mesotrophic (by $62 \%$ on average). In the analysis of drained forest stands, it was found that the largest radial growth was recorded in the canalside position of the sorrel pinery ( $7.2 \%$ on average). This may be due to the closer location of the channels of the regulatory network relative to other objects of the study.

The growth analysis of late wood stem mass identified that in all forest stands the growth of late wood varies from 29 to $37 \%$ of the total radial growth of trees. In marshy forest stands, the proportion of late wood from the total growth is $32 \%$. In intensively and extensively drained plantings, this figure equals $33 \%$ and $31 \%$, respectively.

Table 2

The average growth of late wood by decades

\begin{tabular}{|c|c|c|c|c|c|c|}
\hline \multirow{2}{*}{$\begin{array}{c}\text { Number SP, } \\
\text { tree age }\end{array}$} & \multicolumn{6}{|c|}{ Average radial growth late wood $(\mathrm{mm}) *$ by decade } \\
\hline & $2018-2010$ & 2009-2000 & 1999-1990 & 1989-1980 & 1979-1970 & 1969-1960 \\
\hline \multirow{2}{*}{1,99 years } & 0,087 & 0,134 & 0,075 & 0,075 & 0,153 & 0,157 \\
\hline & 2,2 & 3,4 & 1,9 & 1,9 & 3,9 & 4,0 \\
\hline \multirow{2}{*}{2,114 years } & 0,071 & 0,122 & 0,047 & 0,047 & 0,091 & 0,047 \\
\hline & 1,8 & 3,1 & 1,2 & 1,2 & 2,3 & 1,2 \\
\hline \multirow{2}{*}{3,44 years } & 0,201 & 0,370 & 0,350 & 0,535 & 0,256 & \\
\hline & 5,1 & 9,4 & 8,9 & 13,6 & 6,5 & 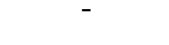 \\
\hline \multirow{2}{*}{4,42 years } & 0,181 & 0,283 & 0,291 & 0,311 & & \\
\hline & 4,6 & 7,2 & 7,4 & 7,9 & - & - \\
\hline \multirow{2}{*}{5,63 years } & 0,130 & 0,260 & 0,240 & 0,264 & 0,287 & 0,256 \\
\hline & 3,3 & 6,6 & 6,1 & 6,7 & 7,3 & 6,5 \\
\hline \multirow{2}{*}{6,63 years } & 0,157 & 0,228 & 0,244 & 0,291 & 0,315 & 0,342 \\
\hline & 4,0 & 5,8 & 6,2 & 7,4 & 8,0 & 8,7 \\
\hline
\end{tabular}

The greatest growth of late wood in annual rings was found in the period from 1980 to 1989 compared to other time lengths (42\% higher). In our opinion, the hydrotechnical amelioration has had an impact, since it was carried out from 1972 to 1984 (taking into account the adaptation process after the construction of canals). The smallest radial growth of forest stands was recorded from 1969 to 1960 (that is, before forest drainage).

\section{Main conclusions:}

1) Maximum stock of pine trees in intensively dried bilberry pine forest;

2) On the mesotrophic type of peat deposit after hydrotechnical amelioration, the average radial growth of trees is 0.025 inch $(0.63 \mathrm{~mm})$, and in the marshy pine forest with similar soil conditions it is three times less;

3) The largest current growth over the last five years in intensively drained forest stands is 0.197 inch $(5.25 \mathrm{~mm})$, and the growth in extensively drained $39 \%$ and in the marshy pine forests is $43 \%$ lower than in the more intensively drained;

4) The greatest width of the annual rings for the entire period of growth in the marshy pine forest on soils of the megatrophic waterlogging type, and over the last five years in the dried sorrel pinery in the interchannel position;

5) In drained pine forests, a significant percentage of dry fir undergrowth was recorded

6) The predominant category of undergrowth is medium, occupying $74 \%$ of all young trees; reliable undergrowth in the near-channel position is $33 \%$ more than in the interchannel space; on the whole, the reafforestation by quantity per hectare (acre) is unsatisfactory under dry conditions.

$$
* * *
$$

1. Lifetime and incidental use of drained forests in the Vologda region / N.A. Druzhinin [and colleagues]; under gen. edit. of A.S. Novoselova. - Vologda: IC SDFA, 2011. - 192 p.

2. Melekhov, I.S. Forest science / I.S. Melekhov. - Moscow: MSFU, 2003. - 398 p.

3. Feklistov, P.A. Biological and ecological specifics of pine growth in the northern subzone of the European taiga / P.A. Feklistov, V.N. Evdokimov, V.M. Barzut. - Arkhangelsk: IPC ASTU, 1997. - 140 p.

4. Tishin, D.V. Dendroecology (tree ring analysis technique) / D.V. Tishin. - Kazan: Kazan University, 2011. $-33 \mathrm{p}$ 